\title{
Ultrastructural characteristics of Nematopsis sp. oocysts (Apicomplexa: Porosporidae), a parasite of the clam Meretrix meretrix (Veneridae) from the Arabian Gulf, Saudi Arabia
}

\author{
Abdel-Azeem S. Abdel-Baki ${ }^{1,2}$, Saleh Al-Quraishy ${ }^{1}$, Mohamed A. Dkhil ${ }^{1,3}$, Ibraheem Al Nasr ${ }^{4}$, Elsa Oliveira ${ }^{5}$, \\ Graça Casal $^{5,6}$ and Carlos Azevedo ${ }^{1,5}$
}

\author{
${ }^{1}$ Zoology Department, College of Science, King Saud University, 11451 Riyadh, Saudi Arabia; \\ ${ }^{2}$ Zoology Department, Faculty of Science, Beni-Suef University, Beni-Suef, Egypt; \\ ${ }^{3}$ Department of Zoology and Entomology, Faculty of Science, Helwan University, Egypt; \\ ${ }^{4}$ Science Department, Teacher's College, Qassim University, Saudi Arabia; \\ ${ }^{5}$ Department of Cell Biology, Institute of Biomedical Sciences (ICBAS/UP) and Laboratory of Pathology, Interdisciplinary Centre \\ of Marine and Environmental Research (CIIMAR/UP), University of Porto, Lg. Abel Salazar no. 2, 4099-123 Porto, Portugal; \\ ${ }^{6}$ Departamento de Ciências, Instituto Superior de Ciências da Saúde - Norte (CESPU), 4585-116 Gandra, Portugal
}

\begin{abstract}
This paper describes the fine structure of oocysts of Nematopsis sp. (Apicomplexa, Porosporidae) found in the abductor muscles of seawater clams, Meretrix meretrix (Linnaeus, 1758) (Veneridae), collected near the city of Dammam $\left(6^{\circ} 17^{\prime} 0^{\prime \prime} \mathrm{N}\right.$, $50^{\circ} 12^{\prime} 0^{\prime \prime E}$ ) in the Arabian Gulf off the coast of Saudi Arabia. Oocysts of an ellipsoidal shape were found among myofibrils of the abductor muscles of infected clams. Each oocyst is composed of an oocyst wall surrounding a single uninucleate vermiform sporozoite located in the lumen of the oocyst wall. The thin oocyst wall $(0.70-0.85 \mu \mathrm{m}$ thick) is composed of homogenous electron-lucent material formed by three layers of equal-thickness. The oocyst wall contains a plano-convex opercular-like structure about $2.5 \mu \mathrm{m}$ in diameter and $0.75-0.90 \mu \mathrm{m}$ thick, composed of a homogenous material with moderate electron density. The oocyst is of an ellipsoidal shape and is $15.6 \pm 0.6 \mu \mathrm{m}$ long and $11.1 \pm 0.7 \mu \mathrm{m}$ wide. Externally, the oocyst wall is surrounded by a complex dense network of numerous anastomosed microfibrils, which are attached to the oocyst wall, forming 2-3 layers and extending towards the periphery, at some points penetrating amongst the host cells. The myofibrils in some cases show evident aspects of lysis as a consequence of the appearance of lysosome-like vesicles. Lacking knowledge of a complete life cycle and/or molecular data precluded the conclusive identification of this species.
\end{abstract}

Keywords: Nematopsis, oocyst, ultrastructure, Meretrix, Saudi Arabia

Species of Nematopsis Schneider, 1892 (Apicomplexa) are hetereoxenous gregarine parasites commonly infecting commercially important marine molluscs as intermediate hosts having decapods as their definitive hosts (Schneider 1892, Prytherch 1938, 1940, Théodoridès 1962, Chen 1967, Sprague 1970, Lauckner 1983, Perkins 1991, Bradbury 1994, Jiménez et al. 2002). Nematopsis species have been reported to have monozoic oocysts (spores or sporocysts according to some authors) with a thick wall enclosing a single sporozoite (Sprague and Orr 1955, Théodoridès 1962, Sprague 1970, Desportes et al. 1977, Azevedo and Cachola 1992, Azevedo and Matos 1999, Padovan et al. 2003, Azevedo and Padovan 2004). Recently, some new Nematopsis spp. have been described (Azevedo and Matos 1999, Lima et al. 2001, Jiménez et al. 2002, Azevedo and Padovan 2004). Several unnamed Nematopsis spp. have been reported in bivalve species from different geographic areas (Azevedo and Cachola 1992, Soto et al. 1996, Kim et al. 1998, Berrilli et al. 2000, Tuntiwaranuruk et al. 2004, 2008, Pinto and Boehs 2008). Sporogonic stages have been reported rarely in gastropods (Hatt 1927, 1931, Azevedo and Padovan 2004) and in crustaceans (Kruse 1966, Jiménez et al. 2002). In the present paper, we present light and transmission electron microscope data relating to a porosporidian parasite, Nematopsis sp., which infects a clam from the Arabian Gulf. This is the first description of a Nematopsis sp. from this region.

\section{MATERIALS AND METHODS}

\section{Collection and isolation of specimens}

Fifty adult specimens of the clam Meretrix meretrix (Linnaeus, 1758) (Bivalvia, Veneridae), of marketable size $(\sim 5-6 \mathrm{~cm})$, were collected in May 2011 from the intertidal coast of the 
Arabian Gulf near the city of Damman $\left(26^{\circ} 17^{\prime} 0^{\prime \prime} \mathrm{N}, 50^{\circ} 12^{\prime} 0 " \mathrm{E}\right)$, situated about $380 \mathrm{~km}$ from the city of Riyadh, Saudi Arabia. The living specimens were dissected under a light microscope in order to separate the infected tissues and organs.

\section{Light and transmission electron microscopy}

Only the abductor muscles were infected by oocysts, morphologically identified as belonging to the genus Nematopsis. Some living parasitized clams presented gaping valves and abductor muscles that appeared to have weak contractile power. The infected tissues containing some isolated oocysts were photographed using a light microscope with Nomarski differential interference contrast (DIC) optics to enable observation and measurements made directly on living oocysts or from photomicrographs obtained from living oocysts utilising image software.

For examination with the transmission electron microscope (TEM), small infected fragments of abductor muscle tissues were fixed in $5 \%$ glutaraldehyde in $0.2 \mathrm{M}$ sodium cacodylate buffer ( $\mathrm{pH} 7.4$ ) for 20 to $24 \mathrm{~h}$, washed overnight in the same buffer at $4{ }^{\circ} \mathrm{C}$, and post-fixed in $2 \% \mathrm{OsO}_{4}$ for $3-4 \mathrm{~h}$ in the same buffer and at the same temperature. After dehydration in an ascending graded ethanol series and propylene oxide, the tissues were embedded in Epon. Semi-thin sections for light microscope examination were stained with methylene blue-Azur II. Ultrathin sections were sectioned using a diamond knife, double-stained with aqueous uranyl acetate and lead citrate and were then observed and photographed in a JEOL 100CXII TEM operated at $60 \mathrm{kV}$.

\section{RESULTS}

\section{Light microscopy}

The parasites, represented by several dispersed oocysts, each formed by an oocyst wall and internal uninucleate vermiform sporozoite, were observed in squash preparations among the myofibrils of the abductor muscle tissues of the bivalve Meretrix meretrix. Similar aspects of the oocysts were observed in semithin sections (Fig. 1). Among the oocysts some empty oocyst walls, without the correspondent sporozoite, were observed (Fig. 2). Phagocytes and parasitophorous vacuoles were never observed. In the squash preparations observed by light microscope 22 of $50(44 \%)$ specimens were infected by oocysts.

\section{Transmission electron microscopy}

Each oocyst was formed by an oocyst wall surrounding a single uninucleated vermiforme sporozoite accommodated in the oocyst lumen. The oocyst wall $(0.70-0.85 \mu \mathrm{m}$ thick) was composed of three equal-thickness layers of homogenous material. This structure was composed of homogenous material with structures of moderated electron density, less dense than the oocyst wall (Fig. 3). Some empty oocysts, without the correspondent sporozoite, but having a similar ultrastructural organization as the oocyst wall, were also observed (Fig. 4). By serial ultra-thin longitudinal and transversal sections it was possible to determine that the oocysts were $15.6 \pm 0.6 \mu \mathrm{m}$ long and 11.1 \pm 0.7 wide $(\mathrm{n}=20)$. Each sporozoite was accommodated as a coiled vermiform containing a spherical nucleus ( $\sim 2 \mu \mathrm{m}$ in diameter) with a large nucleolus $(\sim 1 \mu \mathrm{m}$ in diameter) and a cytoplasm with numerous small vacuoles and vesicles (Figs. 3, 5). The nucleus had a moderated homogenous electron-dense matrix without evidence of heterochromatin (Fig. 7). This matrix was in close contact with the internal face of the oocyst wall (Figs. 3, 5, 7).

The oocyst wall was in turn in close contact with a complex dense network of numerous anastomosed microfibrils, which projected from the periphery of the oocyst wall towards the surrounding host cells, with which were in direct contact (Figs. 5-8). Indeed, the close contact between the oocyst wall and the dense layers of the aggregated microfibrils caused that it was difficult to observe the outline of the oocyst wall (Figs. 3, 5, 7, 8). This complex aggregation of microfibrils was composed of two layers with different orientation and organization (Figs. 6-8). The internal layer, which was in close contact with the oocyst wall, was denser with a greater concentration in the network of the microfibrils, whereas the external layer was less dense and presented some projections among the cells of the host (Figs. 3, 5-8). These projections were in direct contact with the myofibrils and other cells of the host, and some lysosomal-like structures were observed among them (Fig. 6). The surrounding myofibrils and other cells of the host appeared degraded (Figs. $6,8)$. No phagocytic cells and parasitophorous vacuoles were observed surrounding the oocyst of the parasite.

\section{DISCUSSION}

The ultrastructure of the oocyst described in the present work corresponds to that reported for sporogony of species of the family Porosporidae infecting tissues of molluscs (Sprague 1970). This family contains only two genera, Porospora Schneider, 1892 and Nematopsis. Between these two genera the most usual characteristic used in taxonomic distinction is the presence or absence of an oocyst wall (Hatt 1927, Sprague 1970). Species of Porospora are characterized by possessing a naked oocyst without a wall, while those of Nematopsis are defined as having oocyst with a thick oocyst wall enclosing a single vermiform sporozoite (Hatt 1931, Sprague 1970, Azevedo and Matos 1999).

Until recently, most species of Nematopsis were described using light microscopy or illustrated by schematic drawings based on light microscopy (Hatt 1927, Prytherch 1938, 1940, Sprague 1949, 1970, Belofastova 1996, Soto et al. 1996, Tuntiwaranuruk et al. 2004, Pinto and Boehs 2008). Only a few species have been studied by TEM (Azevedo and Cachola 1992, Azevedo and Matos 1999, Padovan et al. 2003, Azevedo and Padovan 2004). Several unnamed Nematopsis spp. from bivalve species of different geographic areas were reported as infecting a variety of mollusc species (Azevedo and Cachola 1992, Kim et al. 1998, Berrilli et al. 2000, Canestri-Trotti et 
Abdel-Baki et al.: Ultrastructure of Nematopsis sp. from Meretrix meretrix
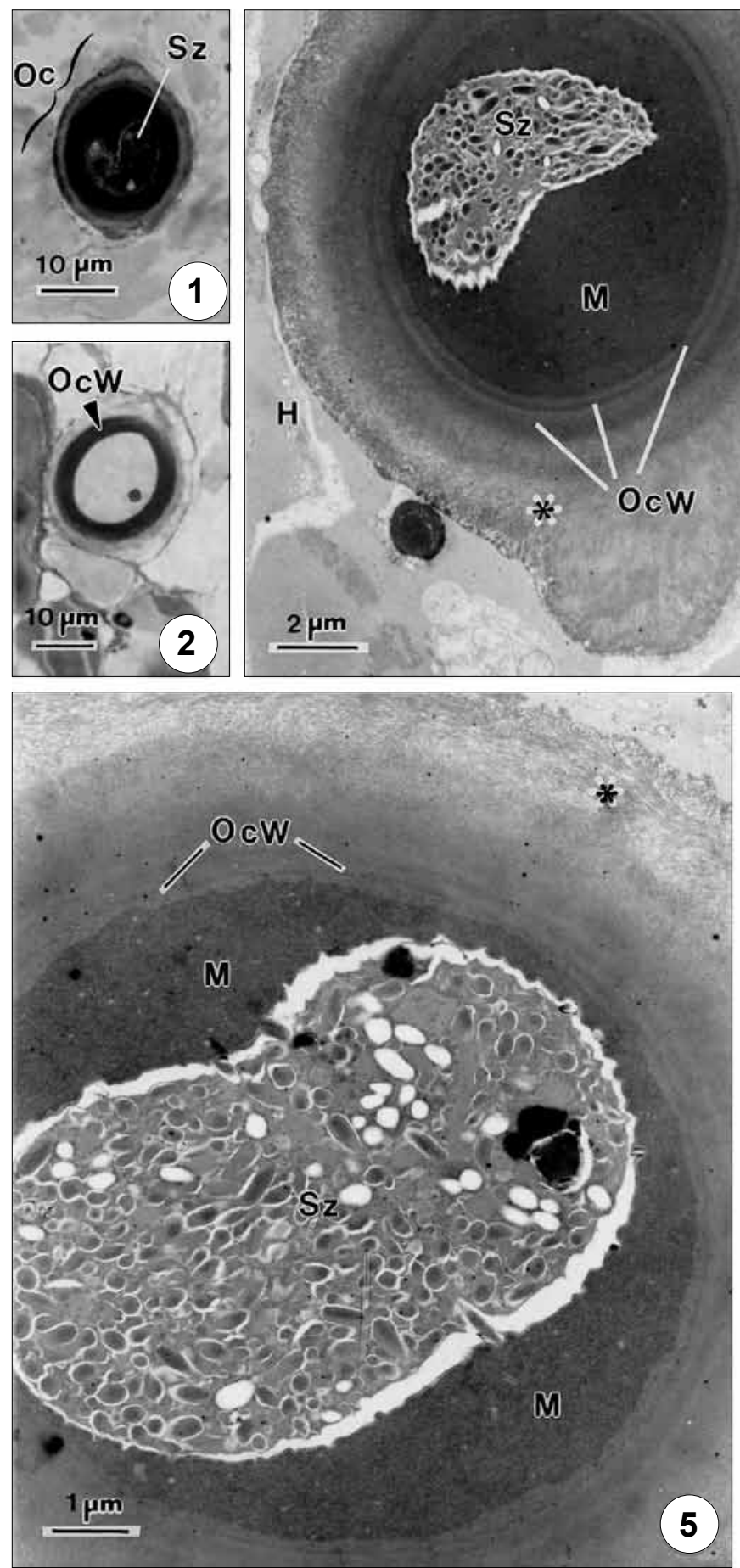
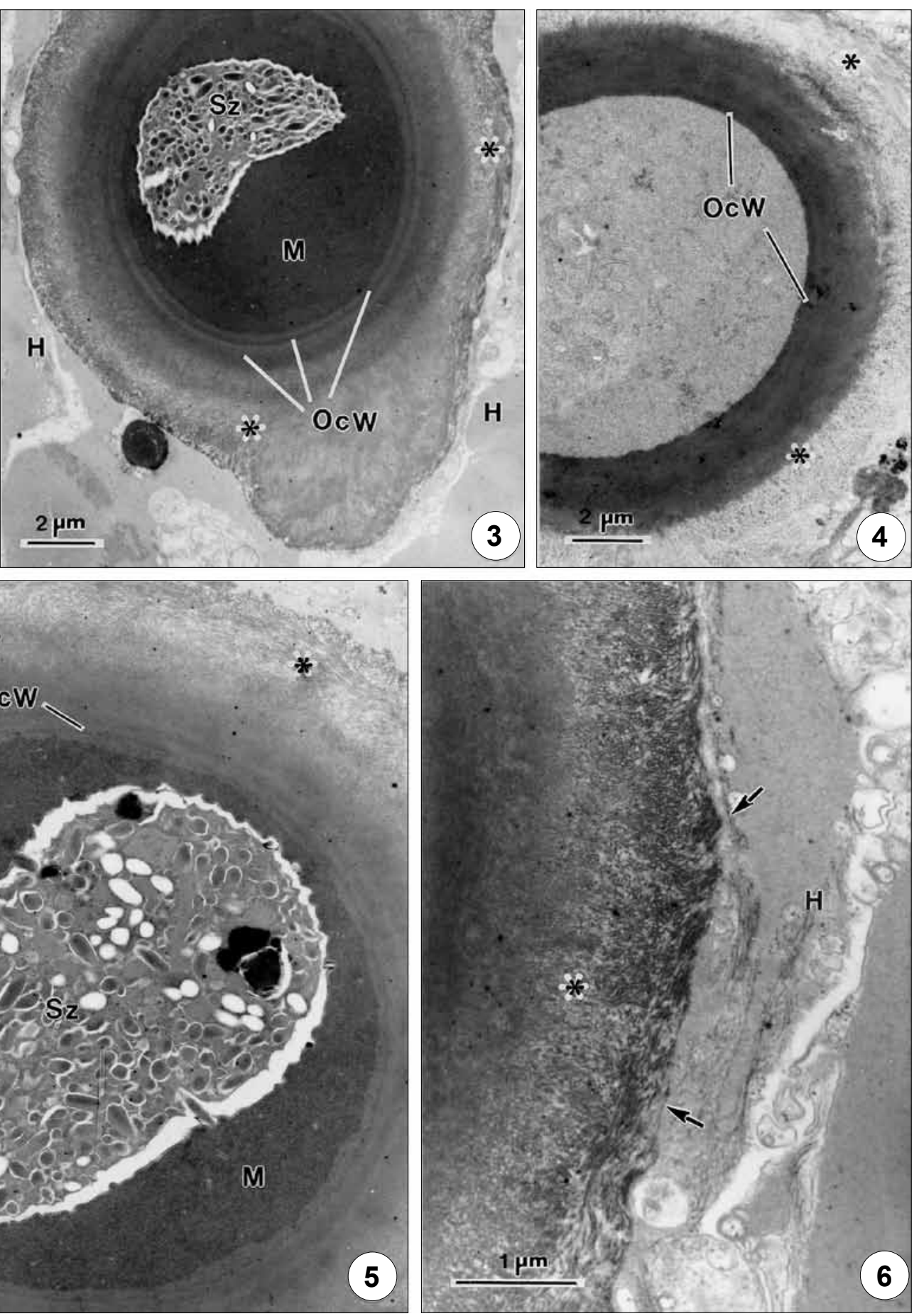

Figs. 1-6. Light and transmission electron microscopy micrographs of the apicomplexan gregarine, Nematopsis sp., a parasite found among the myofibrils of the abductor muscle of the bivalve Meretrix meretrix. Fig. 1. Light microscope (Nomarski differential interference contrast) observation of an oocyst containing a single sporozoite located among the surrounding myofibrils. Fig. 2. Semithin section showing an empty oocyst wall after the sporozoite excystment. Fig. 3. Ultrastructural transverse section of an oocyst showing the sporozoite, the surrounding dense matrix, the oocyst wall, and the external complex network of anastomosed microfibril layers $(*)$. At the periphery some aspects of lysis among the host cells can be observed. Fig. 4. Ultrastructural aspect of the oocyst wall of an empty oocyst after the excystment of the sporozoite showing the organization of the wall and the peripheric microfibrillar organization (*). Fig. 5. Aspect of an oocyst section showing sporozoites and their vesicular organization, the surrounding dense matrix, oocyst wall and the external microfibrillar organization $\left(^{*}\right)$ closely adherent to the oocyst wall. The outline between these two structures is not well evident. Fig. 6. Detail of the external microfibrillar arrangement adherent to the wall and projected towards the periphery contacting directly the myofibrils of the abductor muscle $(\mathrm{H})$. Abbreviations: $\mathrm{H}$ - host cell; $\mathrm{M}$ - matrix; Oc - oocyst; OcW - oocyst wall; $\mathrm{Sz}$ - sporozoite. 
al. 2000, Carballal et al. 2001, Lima et al. 2001, Tuntiwaranuruk et al. 2004).

The most evident difference found in the present description compared to previously described species was in the complex ultrastructural organization of the network of anastomosing microfibrils that formed an adherent wall-like structure around the oocyst wall. The oocyst of $N$. mytella contained a complex network of numerous anastomosed microfibrils adherent to their oocyst wall (Azevedo and Matos 1999, Padovan et at. 2003) located in the parasitophorous vacuoles, but these structures were different in the present Nematopsis sp. The microfibrillar complex surrounding the oocyst wall of the present species has a very electron dense ultrastructural organization, not included in a parasitophorous vacuole, whereas N. mytella has a loose microfibrillar organization, externally contacting the phagocyte (Azevedo and Matos 1999, Padovan et al. 2003). When comparing the oocyst of Nematopsis sp. in the present study we observed that these structures surrounding the oocyst wall have not been reported in any other Nematopsis spp.

On the other hand, comparing the oocyst measurements, we observed that the oocysts of Nematopsis gigas, described from the marine gastropod Nerita ascencionis, are the largest, measuring $21.9 \times 11.5 \mu \mathrm{m}$ (Azevedo and
Padovan 2004), while those of $N$. duorari measure 18.9 $\times 9.8 \mu \mathrm{m}$ (Kruse 1966), and N. prytherch, $19 \times 16 \mu \mathrm{m}$ (Sprague 1949), i.e. they are somewhat smaller. The oocysts of the present Nematopsis sp. measuring $~ 15.6$ $\times 11.1 \mu \mathrm{m}$ are therefore one of the smallest among the species of this genus that have been previously described (Table 1), except that those of N. mytella $(11.5 \times 8.2)$ remain smaller than those of the present species.

Table 1. Comparative character of the oocysts of different Nematopsis spp., including measurements (in $\mu \mathrm{m}$ ).

\begin{tabular}{|c|c|c|c|}
\hline Nematopsis spp. & Hosts & $\begin{array}{c}\text { Oocyst } \\
\text { length } \times \text { width }\end{array}$ & References \\
\hline N. schneideri & Mytilus edulis & $12 \times 7-8$ & Léger 1903 \\
\hline N. prytherch & Oyster & $\begin{array}{l}20 \times 11 \\
19 \times 16\end{array}$ & $\begin{array}{l}\text { Prytherch } 1940 \\
\text { Sprague } 1970\end{array}$ \\
\hline N. duorari & Pelecypod molluscs & $18.9 \times 9.8$ & Kruse 1966 \\
\hline N. legeri & $\begin{array}{l}\text { Porospora gallopro- } \\
\text { vincialis }\end{array}$ & $13-16 \times 7-8.1$ & Belofastova 1996 \\
\hline N. portunidarum & Cerastoderma edule & $10-11 \times 6.8-7$ & Belofastova 1996 \\
\hline N. incognito & $\begin{array}{l}\text { Cerastoderma } \\
\text { lamarcki }\end{array}$ & $\begin{array}{l}15-15.7 \times \\
10.5-11.7\end{array}$ & Belofastova 1996 \\
\hline N. mytella & Mytella guyanensis & $11.5 \times 8.2$ & $\begin{array}{l}\text { Azevedo and } \\
\text { Matos } 1999\end{array}$ \\
\hline N. gigas & Nerita ascencionis & $21.9 \times 11.5$ & $\begin{array}{l}\text { Azevedo and } \\
\text { Padovan } 2004\end{array}$ \\
\hline Nematopsis sp. & Meretrix meretrix & $15.6 \times 11.1$ & Present study \\
\hline
\end{tabular}

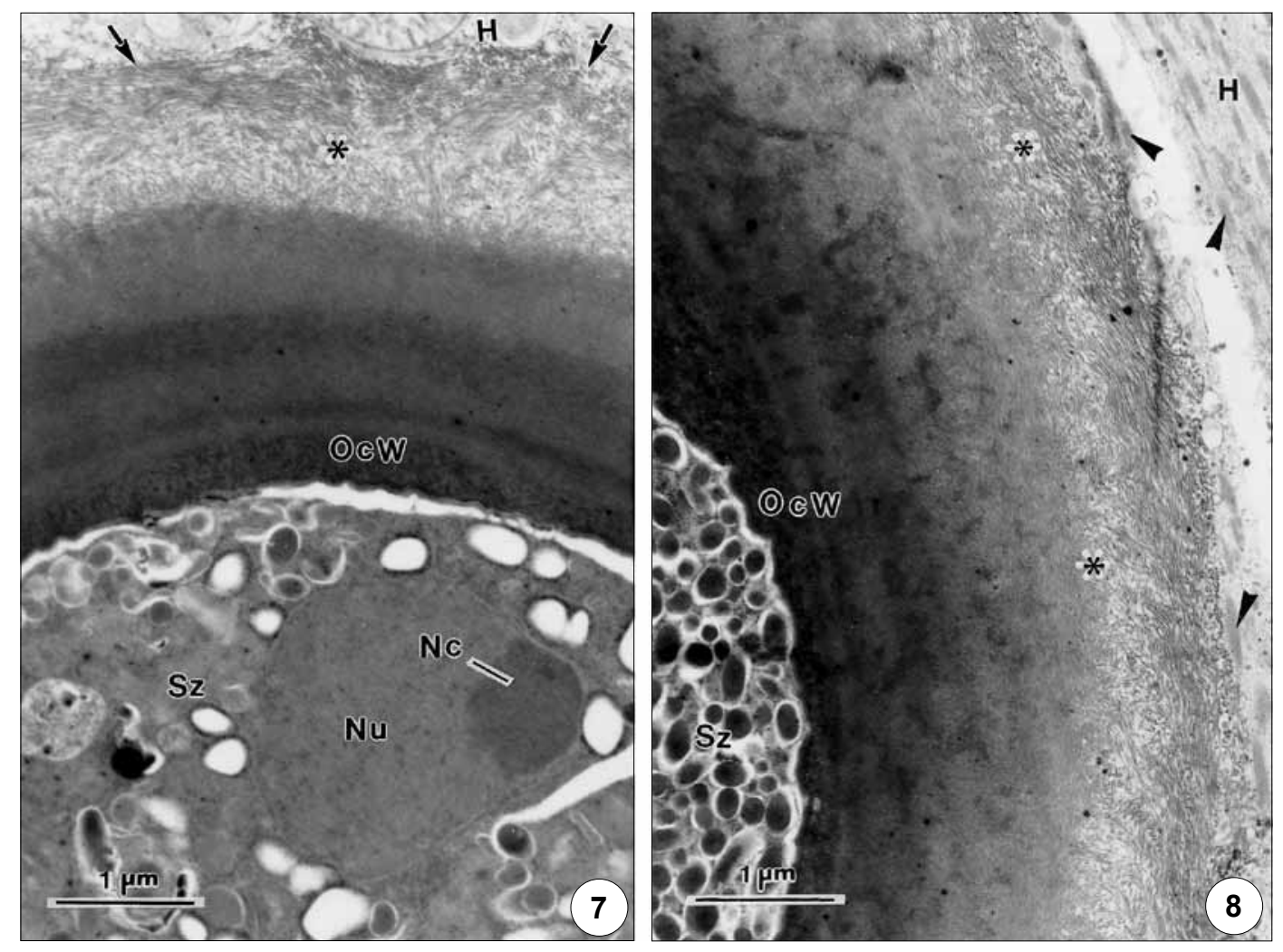

Figs. 7, 8. Transmission electron microscopy micrographs of the apicomplexan gregarine, Nematopsis sp., a parasite found among the myofibrils of the abductor muscle of the bivalve Meretrix meretrix showing some details of the oocysts. Sporozoite, the nucleus and a nucleolus, the oocyst wall and the microfibrillar layer $(*)$ in close contact (arrows) with the cells of the host, where there are some sections of the myofibrils (arrowheads). Abbreviations: $\mathrm{H}$ - host cell; $\mathrm{Nc}$ - nucleolus; $\mathrm{Nu}$ - nucleus; OcW - oocyst wall; $\mathrm{Sz}$ - sporozoite. 


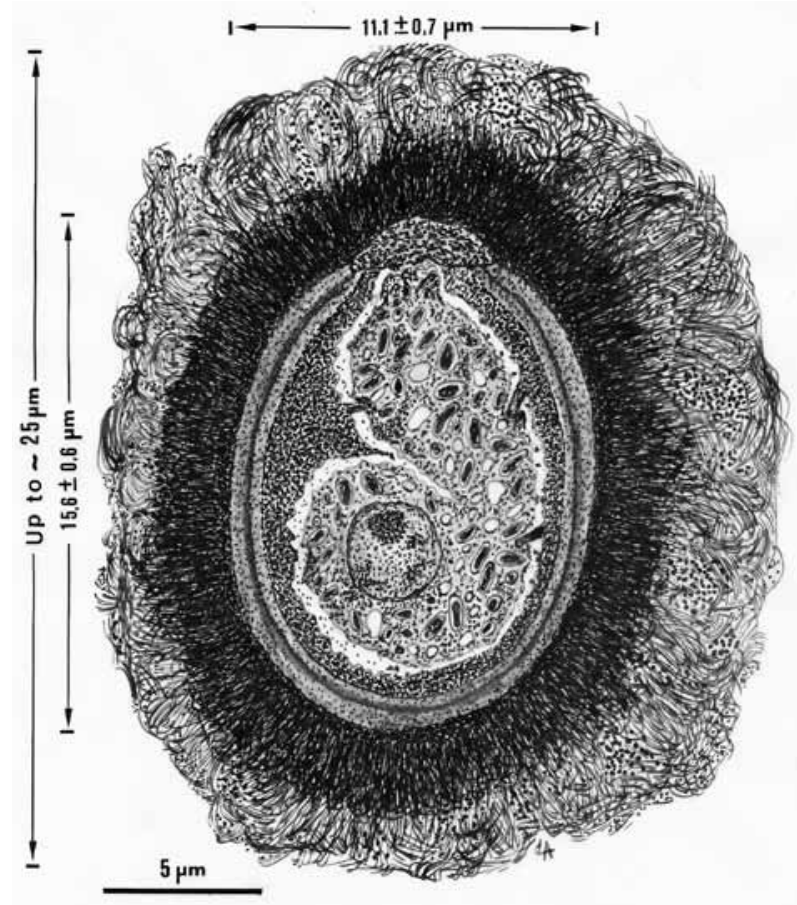

Fig. 9. Schematic drawing of an oocyst of Nematopsis sp., showing all oocystic components described on the basis of serial ultrathin sections.

In the present study phagocytic cells and parasitophorous vacuoles were not observed. The lysis activity corresponding to the presence of this parasite is clearly evident in some lysosomal aspects of the host cell, which shows a degree of ultrastructural degradation in the zone that is in close contact with the more external oocyst microfibrils.

Based on these morphologic differences, including the oocyst measurements and the presence of the complex microfibrillar network adherent to the oocyst wall, the absence of phagocytic cells encasing the oocyst, as well as the geographic host localization and host specificity, we expected the present species to be a new one. However, lack of the complete life cycle and/or molecular data precluded the complete identification of the present species. Curiously, some of the clams infected with Nematopsis sp. described in the present paper were simultaneously infected by cysts containing trophozoites of Perkinsus sp. This occurrence has been reported in some other bivalve species (Canestri-Trotti et al. 1998, 2000).

\section{Taxonomic Summary}

Phylum Apicomplexa Levine, 1970

Class Sporozoa Leuckart, 1879

Order Eugregarinida Léger, 1900

Family Porosporidae Schneider, 1899

Genus Nematopsis Schneider, 1892

Nematopsis sp.

Specific diagnosis: oocysts among the myofibrils of the abductor muscles, each containing only one sporozoite (Figs. 1-3). No other organ or tissue was infected by this parasite. The oocyst is $15.6 \pm 0.6 \mu \mathrm{m}$ in length by 11.1 $\pm 0.7 \mu \mathrm{m}$ in width $(\mathrm{n}=50)$, each containing a single uninucleate vermiform sporozoite (Figs. 1-3). The oocyst wall is $0.70-0.85 \mu \mathrm{m}$ thick and is covered by a plano-convexlike operculum hardly noticed $(\sim 2.5 \mu \mathrm{m}$ in diameter and $\sim 0.75 \mu \mathrm{m}$ thick) (Fig. 3). The oocyst wall is surrounded by a complex network of numerous anastomosing microfibrils that project from the oocyst wall towards the periphery contacting the host cells (Figs. 10, 11). These microfibrils are adherent to the oocyst wall forming a wall-like structure surrounding the oocyst wall. In many of the ultrastructural observations the outline of the oocyst wall was difficult to distinguish (Figs. 3, 5, 7, 8).

Type host: The oocysts were observed among the myofibrils of the abductor muscle tissues of the marine clam Meretrix meretrix (Veneridae).

L o c a lity: Arabic Gulf coast $\left(6^{\circ} 17^{\prime} 0^{\prime \prime} \mathrm{N}, 50^{\circ} 12^{\prime} 0^{\prime \prime} \mathrm{E}\right)$ near city of Dammam of Saudi Arabia.

Site of infection: Myofibrils of abductor muscles.

Prevalence: $44 \%(22 / 50)$.

Material deposited: Glass slide with semithin sections is deposited in the Museum of the Zoology Department, College of Science, King Saud University, Riyadh City, Saudi Arabia with registration no. N-22-2011.

His to pathology: The myofibrils of the abductor muscles of the infected clams that are in contact with the oocysts show some aspects of lysis, and the abductor muscle seem to have weak contractile power.

Acknowledgments. The authors are thankful for the funding support of the Applied National Research Project (NPAR3-(15)), Deanship of Scientific Research, King Saud University, Riyadh, Saudi Arabia. The authors also acknowledge the assistance of Mr. Karl Woodgett in proofreading this paper.

\section{REFERENCES}

Azevedo C., Cachola R. 1992: Fine structure of the apicomplexa oocyst of Nematopsis sp. of two marine bivalve molluscs. Dis. Aquat. Org. 14: 69-73.

Azevedo C., Matos E. 1999: Description of Nematopsis mytella n. sp. (Apicomplexa), parasite of the mussel Mytella guyanensis (Mytellidae) from the Amazon estuary and description of its oocysts. Eur. J. Protistol. 35: 427-433.
Azevedo C., Padovan I. 2004: Nematopsis gigas n. sp. (Apicomplexa), a parasite of Nerita ascencionis (Gastropoda, Neritidae) from Brazil. J. Eukaryot. Microbiol. 51: 214-219.

Belofastova I.P. 1996: Gregarines of the genus Nematopsis (Eugregarinida, Porosporidae) - parasites of the Black Sea invertebrates. Parazitologiya 30: 159-173. (In Russian with English abstract.) 
Berrilli F., Ceschia G., De Liberato C., Di Cave D., Orecchia P. 2000: Parasitic infections of Chamelea gallina (Molusca, Bivalvia) from commercially exploited banks of the Adriatic Sea. Bull. Eur. Ass. Fish Pathol. 20: 199-205.

Bradbury P.C. 1994: Parasitic protozoa of Mollusca and Crustacea. In: J.P. Kreier (Ed.), Parasitic Protozoa. Academic Press, Inc., San Diego, California, pp. 170-180.

Canestri-Trotti G., Baccarani E.M., Paesanti F., Turolla E. 1998: Nematopsis and Perkinsus infections in Chamelea gallina from Northern Adriatic Sea (Italy). Parassitologia 42: 164.

Canestri-Trotti G., Baccarani E.M., Paesanti F., Turolla E. 2000: Monitoring of infections by Protozoa of the genera Nematopsis, Perkinsus and Porospora in the smooth Venus clam Callista chione from the North-Western Adriatic Sea (Italy). Dis. Aquat. Org. 42: 157-161.

Carballal M.J., Iglesias D., Santamarina J., Soto F.B., VilLALBA A. 2001: Parasites and pathologic conditions of the cockle Cerastoderma edule populations of the coast of Galicia (NW Spain). J. Inverteb. Pathol. 78: 87-89.

Cheng T.C. 1967: Marine molluscs as hosts for symbiosis with a review of known parasites of commercially important species. Adv. Mar. Biol. 5: 1-424.

Desportes I., Vivarès Ch.P., Théodoridès J. 1977: Intérêt taxonomique de l'ultrastructure épicytaire chez Ganymedes Huley, Porospora Schneider et Thiriotia n. g., eugregarines parasites de crustacés. Ann. Sci. Nat. Zool. 19: 261-277.

Hatт P. 1927: Spores de Porospora (Nematopsis) chez un gasteropode. C. R. Soc. Biol. 96: 90-91.

Hatт P. 1931: L'évolution des Porosporides chez les mollusques. Arch. Zool. Exp. Gén. 2: 342-415.

Jiménez R., De Barniol L., Machuca M. 2002: Nematopsis marinus $\mathrm{n}$. sp., a new septate gregarine from cultured penaeoid shrimp Litopenaeus vannamei (Boone), in Ecuador. Aquacult. Res. 33: 231-240.

Kim Y., Powell E.N., Wade T.L., Presley B.J., Sericano J. 1998: Parasites of sentinel bivalves in the NOAA Status and Trends Program: distribution and relationship to contaminant body burden. Mar. Pollut. Bull. 37: 45-55.

Kruse D.N. 1966: Life cycle studies on Nematopsis duorari n. sp. (Gregarina; Porosporidae), a parasite of the pink shrimp (Penaeus duorarum) and pelecypod molluscs. Diss. Abstr. 27 B, 2919-B.

LauCKner G. 1983: Diseases of Mollusca: Bivalvia. In: O. Kinne (Ed.), Diseases of Marine Animals. Biologische Anstalt. Helgoland, Hamburg, pp. 542-548.

LÉGER L. 1903: Sporozoaire parasite des moules et autres lamellibranches comestibles. C. R. Acad. Sci. 137: 1003-1006.
Lima F.C., Abreu M.G., Mesquita E.F.M. 2001: Histopathological assessment of mussel Perna perna at the Itaipu Lagoon, Brazil. Arq. Bras. Med. Vet. Zootecn. 53: 203-206

Padovan I.P., Tavares L.A., Corral L., Padovan P.A., AzeveDo C. 2003: Fine structure of the oocyst of Nematopsis mytella (Apicomplexa, Porosporidae), a parasite of the mussel Mytella falcata and of the oyster Crassostrea rhizophorae (Mollusca, Bivalvia) from the northeastern Atlantic coast of Brazil. Braz. J. Morphol. Sci. 20: 141-145.

Perkins F.O. 1991: "Sporozoa": Apicomplexa, Microsporidia, Haplosporidia, Paramyxea, Myxosporidia, and Actinosporidia. In: F.W. Harrison and J.O. Corliss (Eds.), Microscopic Anatomy of Invertebrates. Vol. 1 (Protozoa). Wiley-Liss Inc., New York, pp. 261-331.

Pinto T.R., Boens G. 2008: Nematopsis sp. (Apicomplexa: Eugregarinida) em Mytella guyanensis (Lamarck, 1819) (Bivalvia: Mytilidae) da região estuarina do Rio Cachoeira, Ilhéus, Bahia, Brasil. Braz. J. Vet. Res. Anim. Sci. 45: 95-100.

Prytherch H.F. 1938: The life cycle of a sporozoan parasite of the oyster. Science 88: 451-452.

PRYTHERCh H.F. 1940: The life cycle and morphology of Nematopsis ostrearum sp. nov. a gregarine parasite of the mud crab and oyster. J. Morphol. 39: 64-66.

SCHNeIder A. 1892: Signalement d'un nouveau sporozoaire. Tabl. Zool. 2.

Soto M., Pascual S., Rodriguez H., Gestal C., Abollo E., Arias C., Estévez J. 1996: Nematopsis spp. Schneider, 1892 (Apicomplexa: Gregarinida) in bivalve molluscs off Ria de Vigo (Galicia, NW Spain). Bull. Eur. Ass. Fish Pathol. 16: 157-160.

Sprague V. 1949: Species of Nematopsis in Ostrea virginica. J. Parasitol. 35: 42.

Sprague V. 1970: Some protozoan parasites and hyperparasites in marine bivalve molluscs. In: S.F. Snieszko (Ed.), A Symposium on Diseases of Fishes and Shellfishes. Special Publ. No. 5. American Fisheries Society, Washington, D.C., pp. 511-526.

Sprague V., OrR P.E. Jr. 1955: Nematopsis ostrearum and N. prytherchi (Eugregarinina: Porosporidae) with special reference to the host-parasite relations. J. Parasitol. 41: 89-104.

THÉODORIDĖs J. 1962: Grégarines d'invertébrés marins de la région de Banyuls. I. Eugrégarines parasites de crustacés décapodes. Vie Milieu. 13: 95-122.

Tuntimaranuruk C., Chalermwat K., Pongsakchat V., Meepool A., Upatham E.S., Kruatrachue M. 2008: Infection of Nematopsis oocysts in different size classes of the farmed mussel Perna viridis in Thailand. Aquaculture 281: 12-16.

Tuntimaranuruk C., Chalermwat K., Upatham E.S., Kruatrachue M., Azevedo C. 2004: Investigation of Nematopsis spp. oocysts in 7 species of bivalves from Chonburi Province, Gulf of Thailand. Dis. Aquat. Org. 58: 47-53.

Accepted 9 March 2012 